\title{
Daily practices, consumption and citizenship
}

\author{
JANE M. MAZZARINO ${ }^{1}$, VALDIR J. MORIGI ${ }^{2}$, CRISTINE KAUFMANN ${ }^{2}$, \\ ALESSANDRA M.B. FARIAS ${ }^{3}$ and DIEFERSOM A. FERNANDES ${ }^{4}$ \\ ${ }^{1}$ Centro Universitário Univates, PPG Ambiente e Desenvolvimento, Centro de Ciências Humanas e Jurídicas, \\ Rua Avelino Tallini, 171, Bairro Universitário, 95900-000 Lajeado, RS, Brasil \\ ${ }^{2}$ Universidade Federal do Rio Grande do Sul, Faculdade de Biblioteconomia e Comunicação, \\ Rua Ramiro Barcelos, 2705, Bairro Santana, 90035-007 Porto Alegre, RS, Brasil \\ ${ }^{3}$ Centro Universitário Univates, PPG Ambiente e Desenvolvimento, \\ Rua Avelino Tallini, 171, Bairro Universitário 95900-000 Lajeado, RS, Brasil \\ ${ }^{4}$ Centro Universitário Univates, Centro de Ciências Humanas e Jurídicas, \\ Rua Avelino Tallini, 171, Bairro Universitário 95900-000 Lajeado, RS, Brasil
}

Manuscript received on October 25, 2010; accepted for publication on December 1, 2010

\begin{abstract}
This paper promotes a reflection on the relationship between daily practices and consumption. Understanding how conflicts, resistance and consensus are generated from daily consumption practices opens up possibilities for reflecting on the construction of sustainability in the context of diversity, one of the landmarks of the globalized world. Within this socio-cultural context, the central issue is: can consumption generate citizenship practices? The concepts of subject and agent help one think about collective action and subjectivation processes and their interferences on the collective consuming behavior. Based on empirical data from a research carried out in the municipality of Estrela in 2007, in the Taquari Valley - Rio Grande do Sul (Southern Brazil) on local reality consumption practices, it was possible to conclude that various reasoning mechanisms and values underlie the daily consumption practices. Citizenship construction, based on consumption practices, depends on the subject's reflection capacity on his/her daily practices or on what goes through the circulation of environmental information based on sociability spaces.
\end{abstract}

Key words: consumption, daily life, environmental practices, citizenship, social representations.

\section{INTRODUCTION}

Consumption and its consequences as a local and global collective process is an object of interdisciplinary studies. Sciences cannot individually encompass the multiple dimensions of the environmental knowledge over which environmental issues arise reflection: economic, political, social, cultural, technological, natural, ethical, communicational-mediatic. These dimensions are moved by social reasoning mechanisms exposed in the social actors' discourses and agendas: media, governments, entrepreneurs, organized and non-organized civil society.

Correspondence to: Jane Márcia Mazzarino

E-mail: janemazzarino@gmail.com
Understanding how conflicts, resistance and consensus are generated from the daily consumption practices opens up possibilities for reflecting on the construction of sustainability in the context of diversity, one of the landmarks of the globalized world. If daily life is a component in the mesh that constitutes the subject as a citizen, it is based on this space that the possibilities and strategies that lead to the citizen's reflection capacity on his/her daily practices must be thought of, so as to change certain social behaviors.

Within this context, specific questions arise and become a research problem: what reasoning mechanisms and values underlie the daily consumption practices? How do consumers perceive and reflect on the impacts 
of consumption on the environment? Can consumption practices constitute citizenship practices? What is the role of sociability spaces in this process?

This article aims at reflecting on these questions that are intertwined with the theoretical dialog on the theme and empirical study carried out in the second semester in 2007 in the municipality of Estrela, in the Taquari Valley, state of Rio Grande do Sul. Semi-structured interviews were applied to forty consumers in a qualitative-natured research. Data were treated through content analysis, and the informers' speech constituted a discursive corpus on the theme, liable to be interpreted under the light of critical reflection ${ }^{1}$. The daily consumption practices and the possibilities of constructing citizenship and the subject in the consumption society were theoretically approached.

\section{COnsumption, Citizenship and SubJect CONSTRUCTION}

The relationships between man and the environment are complex in nature; the former transforms the latter, but he is also transformed by it. There are different processes in this interaction that formulate the 'rules of living together' and unveil the meanings that the human being builds based on his/her relationship with the environment.

The social uses of environmental resources by man in different societies are characterized by his beliefs on their societies' historical-social values, and can be observed through reasoning mechanisms that underlie production, consumption and waste disposability processes. A study on the social uses of natural resources presents perspectives to understand their dynamics and organize strategies for sustainable practices. According to Portillho (2005, page 11), "reflections on what is necessary or superfluous lead to the issue of limits: are there limits in nature for human production and disposal? And if so, how to establish limits?" In this sense, the author questions whether consumption can be an emancipating element in the construction of full citizenship.

\footnotetext{
1 This study is associated to the research 'Environmental Practices and Social Networks: investigating the reality on solid domestic waste in the Taquari Valley, Rio Grande do Sul' connected to the Graduate Program on Environment and Development from Univates University Center.
}

Portilho (2005) spots three historical moments in the political discourse about environmental crisis, and identifies that the third one is strongly related to consumption. In the $70 \mathrm{~s}$ the population boom was thought of based on the impacts it generated on production and the planet's natural resources. From the Stockholm Conference (1972), the main argument was that the cause of the crisis would lie in the production style of industrialized nations, which demands a great deal of resources and, on the other hand, produce pollution. This line of thought generated a conflict between northern and southern hemispheres. In a second moment the emphasis on the demographic growth was replaced by the focus on productive and technological models. Then there is a focus on the impact of forms of production on the environment, thus generating a debate between governments and the environmental movement ${ }^{2}$.

The discourse that arose from the 90s onward is still current in the international environmental thought. The author supports that consumption impacts are now seen as the main cause of environmental problems once the excessive consuming is "socially unfair and morally indefensible, as well as environmentally unsustainable" (Portilho 2005, page 15). Based on this concept the consumption according, to contemporary world models, is not equalitarian and surpasses the capacity for natural resources reproduction and waste absorption.

As per Portilho, consumption emerges as a consequence of the Industrial Revolution, especially in the middle class of the 18th century English society. "Consumerism in its origins has been associated to ideals of individual freedom and to the appreciation of families living together, through making homes cozier, materially speaking". (Portilho 2005, page 88). Economical, technological and social changes will be reflected in new consumption ways that, in turn, produce new changes of the same nature. The emergence of mass communication means speed up this process. The changes brought about by the Industrial Revolution generate a cultural revolution that is accelerated in the $20^{\text {th }}$ century.

\footnotetext{
2 In this same decade, the cultural revolution splashes brought about a rejection to the dominant culture, especially the young people who criticized the system and the rational models, the political system, the American way-of-life and socialism. (Paes 1997).
} 
As opposed to Portilho, Barbosa (2004) refutes the idea that the Industrial Revolution has been a landmark in the change of the forms of consumption. According to this author, there are findings supporting that its origin can be traced back to the $16^{\text {th }}$ century, when the setting was characterized by the trade expansion with the East. Lipovetsky (1989) associates the early days of consumption as it is known today to the end of the Middle Age in France, when relationships between court and bourgeoisie are altered. According to this author, consumption is mostly affected by the extension of fashion to private life, not only by economical changes.

If nowadays consumption emerges as a cultural theme, this is partially due to the growing mediatization process that environmental issues go through with the emergence of information and communication technologies, which somehow bring nations closer together. The same mediatic structure that mediates consumption globalization also makes global the many discourses on sustainability, mobilizing public opinion and new rules for living with the environment. Having this in mind, Garcia Canclini's (1995) enquiry is appropriate: is consumption suitable for provoking thinking? According to this author, thinking about the ways the social actors (citizens) appropriate the goods they consume and how these are symbolically represented leads to the reflection on how cultural identities in the contemporary world are being forged. The symbolic ways through which each one represents himself/herself to the other in the public scope are reflected in the daily actions, in the social positions he/she subscribes, in the social groups he/she connects to, and the way he/she constructs his/her subjectivity. Thus, the way one performs the politics of the daily life and the art of making himself/herself, of choosing among the available options, reveals who each one is.

Under this light, the act of consuming is political, also presupposing ethical, cultural, economical and social choices, still characterized by the lack of information of the consumers on production processes. It is a contradiction if one takes into account that one lives in a society defined by constant information flow. The consumer, thought of as a social actor, might or might not exert his/her citizenship through his/her daily choices. Reflecting about these choices that end up outlining his/ her life style, it can be concluded that the consumer ends up becoming an active contributor to some economical and political reasoning mechanisms at the expense of others. Thus, consumption may become an emancipating competence. According to Portilho (2005, page 77):
[...] one cannot present the individual as the sys- tem's pure victim; on the contrary, one needs to observe the reasoning mechanisms of cultural be- longing, differentiating and hostilizing within dis- tinct class processes, which is fundamental in the social dynamics. According to this reasoning mech- anism, consumption is not a function of satisfying individual needs, but a social activity, once these needs are organized according to an objective so- cial search for signs and differentiation.

Thus, consumption practices in the capitalist scope are represented as cultural practices bringing environmental consequences. According to this view, it is considered that the offer of environmental information to society is one of the requirements for building citizen$\operatorname{ship}^{3}$.

The relationship between consumption and citizenship involves a degree of complexity due to the multiple mediations the subject is inserted into. Citizenship is a historical category, and as such has had various facets according to each nation's social and cultural context along time. Therefore, to understand it with its diverse manifestations and conceptions, it is necessary to refer to each region or country's historic and social context, as well to the practices of social groups.

In Western society citizenship is related to citizens' rights and duties. As per Vieira (2001), this is the classic view on citizenship developed by Marshall (1967). According to this author, firstly civil rights were demanded $-18^{\text {th }}$ century: individual rights, right to freedom, equality, property, to come and go and to safety. Afterwards there were the political rights $-19^{\text {th }}$ century: freedom to associate and organize politically and electorally. In the $20^{\text {th }}$ century citizenship was related to social rights:

\footnotetext{
3 According to Barros (2004), the access to environmental information is important in consolidating democracy and protecting the environment. This piece of information is clarifying and instructional, enabling individuals to interfere in decision-making processes.
} 
right to work, education, health, retirement and pension funds. Among these social rights it should be included the right to a healthy and sound environment, which is an essential need of people, a collective right in any time and place and, therefore, must be acknowledged as a fundamental right (Dallari 1998). However, the quest for and the recognition of this right cannot only be a concern or responsibility of governments, but rather of citizens and social groups that have to fight for a healthy and preserved environment, demanding it from governments, organizations and individuals.

When considering environment as a historic and cultural heritage, which is a common use property that participates in the construction of identity (personal and collective), the actual citizenship's attitude presupposes a collective quest for its preservation. According to this, consumption should be thought of as a citizen's practice, an attitude of concern and awareness in relation to environmental preservation ${ }^{4}$.

According to Loureiro (2002), citizenship is permanently constructed once it is constituted when it yields meaningfulness to an individual's belonging to a society in each historic phase. It is not conferred, but is related to the individual's participation in the social organization forming the national and international civil society, which has deliberative power. Therefore, citizenship has been incorporating various rights and meanings along time that are related to social-historic changes, such as the globalization phenomenon. According to this, citizenship can take other expression forms. As pointed out by Loureiro (2002, page 76):

Eco-citizenship or planetary citizenship is a concept used to express the insertion of the ecologic ethics and the facets it takes in daily life, in a context that allows becoming individually and collectively aware of both local and global responsibility; its central axis is respecting life and defending the right to it in a world with no geopolitical boundaries. According to this concept, belonging to the humankind and to a unique planet is an aspect to be highlighted.

\footnotetext{
4 Maria Cecília Paoli (1992) supports that the concept of 'historical heritage' is directly related to culture and past evoked by its various forms. They are elements and happenings one wishes to keep, and are collectively meaningful.
}

Still according to this author, when the citizen is referred to as being a free and rational consumer, by emphasizing his/her freedom of choice and individual rights one is using a neoliberal concept of citizenship. The author criticizes this view once it disregards that social inequalities result from market deregulation and poor likelihood of aware actions by individuals. Loureiro (2002) points out that the environment requires collective responsibility and limits, such as the impossibility of satisfying the needs that consumption society imposes on the planet's inhabitants.

According to Portilho (2005, page 105) "[...] the consumption activity and the consumers" own role may provide important possibilities to constitute active social subjects and a return to the status of citizen. Under this light, it is important the distinction made by Touraine (1992) among individual, subject and agent. The individual is defined by the expectation of others and controlled by institutional rules, social roles, and the social system mechanism. The individual who is not constituted as a subject is constituted by the power centers that define and ratify his/her roles. It is a puppet of the dominant ideologies, according to J.M. Mazzarino (unpublished data) $)^{5}$, once he/she consumes society instead of producing and transforming it, submitting himself/herself to those who rule economy, politics and information.

The individual will only become a subject in case he/she opposes the reasoning mechanism of social domination in the name of mechanisms of freedom, free production and of himself/herself. The liberal society emphasizes liberation from desires and satisfaction of individual needs, considering outdated everything that restrains freedom of choice and individual behavior, which limits the collective action which characterizes the subject (Touraine 1992).

The subject is distinguished from the individual because he/she attempts to provide his/her existence with personal meaning. He/she is the constructor/producer of his/her social experience, an active being J.M. Mazzarino (unpublished data) ${ }^{5}$. According to Touraine, the subject is a 'dissident', a 'resistant'. He/she is

\footnotetext{
5 Mazzarino JM. 2005. A cidadania na tecelagem das interações comunicacionais-midiatizadas do movimento socioambiental: um estudo de caso do Centro de Educação Ambiental da Vila Pinto em Porto Alegre. PhD Thesis, São Leopoldo: UNISINOS.
} 
[...] a subject in his/her resistance to the impersonal world of consumption, violence or war. We are continually disintegrated, fragmented and seduced, going from one situation to another, from some stimuli to others. We get lost in the mass of our situations, reactions, emotions and thoughts [...] the subject does never totally identify with himself/herself and remains situated in the order of rights and duties, in the order of morality and not in the order of experience'. (Touraine 2006, page 120, italics by the author)

The subject is, therefore, the one who denounces the consumption society and the reasoning mechanisms of the dominant ideology, thus differentiating himself/ herself from the individual who enjoys this society without criticizing it. According to this perspective, the concept of subject implies in a fight against financial power and authoritarianism, even those coming from the community. This fight goes through each person's daily choices, which in turn are reflected in the conflicts between the individual and collective constructions. One constructs himself/herself as a subject based on these choices J.M. Mazzarino (unpublished 2005) ${ }^{5}$. One of the conflicts arising in this context is when the choices impose a dispute between the individual right to consumption and the collective right to a healthy environment.

For Touraine (1992) the concept of subject cannot be separated from that of the agent. The agent is the one who changes the social and material environment within he/she is placed by transforming work division, influencing decision-making and generating cultural changes. $\mathrm{He} / \mathrm{she}$ is the agent of a social action and movement. $\mathrm{He} / \mathrm{she}$ is an agent of his/her own life, ideas and behaviors. According to Touraine (1992, page 269) "it is through his relationship with the other as a subject that the individual is no longer an element of the social system operation and becomes creator of himself/herself and a producer of society". Based on this approach, it is understood that the subject and the agent, and not the individual, can construct citizenship, which, in the globalized contemporary world characterized by the consumption society, has as its main element the access to environmental information.
Melucci (2004) maintains that the ecologic issue has changed the cultural and social perception of the world, once it reveals the planetary interdependence by shifting the limits of human awareness and actions, as well as resorting to the restructuring of cognitive models and individual's expectations concerning reality. For this author, the ecologic issue has primarily a cultural dimension of the human action, once it is where the issues related to the fate of the humankind are placed. According to Melucci (2004, page 57):

It is not possible to imagine a viable future for life without intervening in the social relationships, symbolic systems and information circulation, as much or more than one intervenes in the technical systems. Those who are concerned about governing complexity by acting on things risk to make a prospective mistake, a kind of substantial short-sightedness. Presently, the efficiency with things depends more on the capacity of acting on the symbolic codes that rule daily life, political systems and production and consumption forms.

For Melucci, more information means greater potential for autonomous action, which in turn means reflexive capacity to produce meaning and motivation to what one is. However, it also means that everybody is more exposed to information, which can control or transform identity in a corrosive way. "To devote oneself to the internal planet means to oppose the conquerors and include this huge awareness heritage into our field of experience, learning to explore, inhabit and cultivate, instead of submitting" (Melucci 2004, page 61). Thus, for us to promote the occupation of the internal planet, Melucci (2004, page 67) proposes that:

The ecology of economic, political and technological choices does not subsist today without the ecology of the daily life, of the words and the signals through which we promote the construction or the destruction of the internal planet. The reflection and communication forms are the ground to which one applies a second level understanding, which already begins to substitute a culture exclusively centered on contents, values and objects. The forms and processes of the human action become extremely important, when the speed of change promotes an 
ever quicker obsolescence and a content substitution. The form of action acquires the value of the word, as much as or more than the content itself.

Based on these assumptions, it can be understood that consumption is a form of action that expresses a discourse regarding consumers' choices, and it can or cannot lead to the construction of citizenship.

\section{The Consumer Within the Consumption Society}

If we take into account Garcia Canclini's reflections (1995, page 76), to whom consumption is a set of socialcultural processes in which products are appropriated and used, the time of disposal refers to the end of the consumption process. Therefore, it also expresses a social use, an ultimate form of appropriating objects, which paradoxically refers to expropriation and disuse.

As per Rocha (2005, page 2), "consumption has been turned into the scope of social distinction articulation, ranked according to the assignment of differential prestige". In the consumption society it is marketed the idea that, the more one consumes, the more status he/she will have, which in turn is linked to the notion of happiness. Nevertheless, as shown by Portilho (2005), consumption also refers to political conflicts and options related to the material world due to the endless needs that are substituted right after they are satisfied, in a continuous motion. Marketing professionals base themselves on needs studies to develop products that 'sell' the idea of a set of benefits that will satisfy consumers.

According to this, the $2^{\text {nd }}$ article of regulation 8.078/90, known as Consumer Protection Code, identifies the consumer as 'every individual or corporate body that acquires or uses a product or a service as the final receiver. Consumers are equated with people's collectivity, though indeterminable, that act intervening in the consumption relationships.' This concept places the consumer as the receiver and user of a product that he/ she appropriates, distinctly from Garcia Canclini's concept according to whom the consumer does not only appropriate it materially, but especially in a symbolic aspect. Therefore, consumption refers to a dialectic movement among the material and symbolic aspects in which consumers differ from each other.

According to Kotler (1994), who is author in the communication and marketing fields, what differenti- ates consumers are the qualities perceived as significant or outstanding in the products, as well as the value assigned to each quality. The potential consumer is the one the marketing professional identifies as being willing and capable of engaging in the value exchange that is proposed to him/her. Kotler (1994, page 377) understands that the "product is something that can be offered to a market for its appreciation, acquisition, use or consumption to satisfy a desire or a need". The consumer, when coming across with a product offered by the market, establishes a preference scale among the goods and services he/she wishes to obtain, choosing the ones that provide him/her with greater satisfaction. As there is a variety of preferences, markets are divided into consumer segments, according to their needs and desires specificities, which results in the development of a great product variation, according to Kotler ${ }^{6}$. For him, desires refer to the need for specific satisfactions to be met. Although peoples' needs are few, their desires are numerous, and are continuously molded and remolded.

This market bias for analyzing consumption is also approached by Featherstone (1995, page 33) to whom consumption culture is based on three aspects: product capitalist expansion with a huge accumulation of material culture in the form of goods and purchase and consumption venues; the product as a creator of bonds and distinctions; and consumption as a reference to feelings. The consumption culture is characterized by the exchange value surpassing the use value. According to this author, the consumption culture refers to the product worlds and the structure coming from it, which become the constituting elements of the contemporary society. Besides their usefulness, goods are used to communicate. Barbosa's reasoning (2004) is in consonance with the one of Featherstone's, but he differentiates consumption society from consumption culture. While the former refers to the capitalist market society, whose characteristic is the accumulation of material culture in the form of goods and services obtained through the purchase based on fashion, the latter refers to the individualistic ideology based on the freedom of choice

\footnotetext{
6 Consumers are categorized into segments according to variables (gender, age, income, education, etc) that allow the agency to define the message characteristics, so that it is compatible with the targetconsumer, as per Kotler (1994).
} 
and the end of the distinction between high and low culture, where the sign is the product.

Baudrillard (1995) deepens the analysis of this relationship between sign and product by stating that the consumption society is based on the search for happiness and equality through obtaining objects and measurable signs. Regarding consumption, it is achieved by men and their needs, which push them to objects that are sources of a never completed satisfaction. Consumption ends up becoming a system of values that implies in the integration of a person to a group, which starts with a control over him/her. The needs would rather be triggered by the value represented by the objects than by the objects themselves, thus producing satisfaction from the implicit meanings of the objects.

This personal satisfaction measured through objects can be characterized by personalization which, according to Lipovetsky, broadens consumption boundaries. According to this author, if initially consumption served differentiation, now it is more and more part of a self well-being and pleasure, characterizing a narcissistic individualism. For him, the ostentation consumption is ceasing to be a model. In its place it emerges the consumption linked to comfort. Thus, this author identifies two phases in the consumption society: the first one, based on the idolatry of the North-American way of life, and the second one, based on the quest for life quality. For him, even with various nature crises (ecologic, economic, etc), consumption will subsist, once it represents the culmination of the hypermodern society. As stated by Lipovetsky, this is not the problematic aspect of the consumption society; the problematic aspect is the fact that it does not include all individuals. Thus, he claims to be in favor of the consumption society, criticizing the apocalyptical thought that is based on the principle that the consumption society originates from advertising manipulation (Lipovetsky 1989).

Based on the concepts and theories presented, one can understand consumption as a social-cultural process that implies in a social positioning based on appropriating an object (material and/or non-material) for what it represents to its consumer. As social positioning, consumption promotes either approaching and/or distancing regarding the group's values, which is reflected in cultural tensions or conflicts. The consumer, upon choosing and appropriating the consumption objects, places himself/herself in the role of an active receiver of the social discourse inherent to the object. When using it, he/she legitimates the symbolic value that the objects assumes for itself and for society due to the qualities and relevance that are assigned to it, which meet satisfaction needs of various natures (physiologic, related to safety, love, affection, esteem, ego, self-achievement, differentiation, social integration, equality, pleasure, happiness, well-being, comfort, life quality, etc...). The consuming action is intrinsic to the human being and refers to a form of social insertion based on the use of objects, which puts the market in motion. This is the basic aspect of the capitalist system.

Therefore, consumption is an act of personal choice, but socially situated, encompassing different kinds of responsibility: social, political, economic, ethical, cultural, ecologic and communicational. These liabilities related to the daily and repetitive action of consumption may or may not be an element in the construction of citizenship, understood here in its sense of exercising rights, but mainly duties of environmental nature. Responsibility for consuming represents the construction of the subject, as defined by Touraine (1992). Emancipating in nature or not, consumption is always an element of social self-representation and, therefore, of identity construction.

Subsequently there is an attempt to describe, based on a local reality, what a citizen's behavior towards daily consumption is like, trying to focus on the informational resources and on what dimensions become clear by analyzing the consumers' reasoning mechanisms. This study was carried out in the municipality of Estrela, in the Taquari Valley - Rio Grande do Sul (southernmost Brazil). The fundamental issues approached were: do consumers realize how consumption impacts the environment? Can consumption generate citizenship practices?

\section{MATERIALS AND METHODS}

According to data from the Statistics and Economy Foundation in 2007, the population in the Taquari Valley is 316,325 inhabitants. This foundation also informs that the mean Social-Economic Development Index in this 
region is $0.73^{7}$. The municipality of Estrela, where the empirical study was carried out, is the $20^{\text {th }}$ in the rank of the above mentioned index. It is one of the oldest municipalities in this region, settled by German immigrants and placed $113 \mathrm{~km}$ away from Porto Alegre, which is the state capital of Rio Grande do Sul. According to data from the Brazilian Institute of Geography and Statistics (IBGE 2008), this city's area is $184 \mathrm{~km}^{2}$ and it has a total population of 29,071 inhabitants, $86.6 \%$ of which live in urban areas. Its economy is mainly based on industry, followed by the commerce and primary sector.

Given the nature of this article, qualitative methodologies were predominantly used when approaching the above setting. Concerning operational techniques and procedures, the following ones were performed: bibliographic research, observation, semi-structured interviews and content analysis. In an attempt to understand the issues presented, interviews were performed involving forty consumers of this municipality. The sample is non-probabilistic (the subjects are chosen according to a specific criterion) and intentional; moreover, consumers were chosen according to accessibility. As per Vergara (2004, page 51), one can select informers for their accessibility and/or because of their kind: "For accessibility: far from any statistic procedure, it selects elements because of the easy access to them" and "[...] for their kind: it selects elements the researcher considers as representative of the target population, which requires a deep knowledge of this population". Based on these considerations, there was a search for subjects of a certain kind among the consumers, who were chosen so as to encompass the various districts of the city, and consequently the income diversity, as pointed out by secondary data. The ones interviewed were in charge of the disposal of the solid domestic waste, regardless variables such as gender, age or education. The interviews were transcribed as a whole. Afterwards, answers of different individuals of each group were organized in a parallel way. Content qualitative and thematic analysis of the answers collected were carried out, and the interviewees' forms of expressions were kept.

\footnotetext{
${ }^{7}$ According to the Economy and Statistics Foundation, the Socioeconomic Development Index encompasses four areas: Education; Income; Sanitation and Households; and Health.
}

\section{RESULTS}

When they were enquired: at the supermarket, when you are doing the shopping, what ends up determining what you pick from the shelf? The most recurrent answers were: price, product quality, need and, finally, they remembered expiration date. Packing was mentioned, usually to refer to an aspect that is not observed even when there is already some information on the theme. 'I do not observe the kind of packing. I do not think whether it is going to cause environmental damage'. Or else: 'I do not pay attention to the packing. I have not become aware yet to worry if it harms the environment.'

An interviewee mentions the packing as a way for the consumer to get rid of commitment or responsibility, according to what follows: 'I never look at the packing. If they are allowed to produce, they should know it has to be collected, once I pay for it to be collected and to know its destination. If it pollutes, the one who manufactures should collect it.' This discourse points to the disregard of the ethical dimension in the consumption reasoning mechanism, once responsibility is passed on to somebody else, as if the individual consumption would not reflect on demands for the industry. Another consumer admits that "we should choose these products with recyclable packing, but the environmentally correct products are usually more expensive.'

When packing determines obtaining a product through its purchase instead of another criterion, it is because it is practical, or because it is 'intact', or the product is 'well-packed', which many times means that the material is not necessarily reusable or recyclable. However, the answers pointed out that the packing is also chosen for the possibility of being reused.

Regarding the excessive amount of plastic bags used in the supermarkets, only one consumer mentioned it as being an environmental problem resulting from consumption. She realizes the need of changing this habit by adopting reusable bags. 'We try not to use plastic bags. I thought it was great that in Lajeado (neighboring town) people use reusable bags. It should be so everywhere, or using baskets as it is done in Germany. It is known that it (plastic) is no good, it is a problem.' This consumer refers to a new practice in the region more observed in developed countries, such as Germany, where most families in Estrela have their ancestors. 
This cultural proximity might be creating an appeal for the use of reusable bags, which was mainly observed in families with greater purchase power.

The ecologic quality of the product to be consumed was mentioned as determining the purchase only by one consumer, who also takes into account whether the manufacturing is national. 'We try to buy ecologic products, made in Brazil. We value brands and expiration date'.

The interviewees consumption practices point to social-cultural reasoning mechanisms that value basically the economic aspect (based on price and practicality) and the communicational-mediatic one (responsible for branding). It is in the balance of cost-quality-brandneed that daily consumption choices are being made, where packing is regarded as something that one rarely, if ever, takes into account, or still, as someone else's responsibility, namely the industry.

The content of the interviews do not signal citizenship construction or eco-citizenship from consumption. Instead of them, what prevails is the old known conventional consumption mechanism, lacking reflection. One of the ways citizens may become aware of the impacts products have on the environment is through information access and the media in charge of publicizing it. Under this light, interviewees were enquired on what communication media they use to obtain information. Radio and television were the two vehicles more often mentioned. Newspaper, magazines and internet, which tend to approach facts more deeply, were the ones less often mentioned ${ }^{8}$. Regarding the question: does media discuss environmental issues? What is reported and how? In none of the answers did the interviewees mention environmental issues, consumption, waste production, even when they stated singly that media tackles the theme 'garbage'. It can be observed that the way the interviewees obtain information is based on traditional media, which focus superficially the issues it approaches. Therefore, consumers have few deeper information sources or sources dealing with the complexity of inter-relationships among environmental issues.

\footnotetext{
$\overline{8}$ A deeper analysis of facts should be done by this media, taking into account their characteristics, but this study points out that Estrela's local newspapers have been approaching environmental themes based on their relationship with the Executive power, not tackling its complexity.
}

There was an attempt to identify what other possible information sources might be tackling these issues, through the question: In the social groups you participate, do people speak about environmental and waste issues? What do they say and what groups do you participate in? Most reported they do not talk about this theme in the social groups they participate, namely: groups of choir, Cancer League, knitting, bowling, water workout, mothers' club, parties). Concerning work, building residents and church meetings to discuss the environmental theme is occasionally approached, according to the interviewees. In residents' associations this theme emerges from the concern about the 'neighborhood cleanliness', and 'each one does his/her best.' It is observed that the environmental issue is not seen as a problem that affects all citizens, society and our planet. The social group tending to tackle it more often (even so with few references) is the family, and it is generally brought up by a member who discussed it in school or college. It tends to emerge also in chats with friends or neighbors. These data confirm the lack of circulation of environmental information in the nonmediatized social venues.

\section{DISCUSSION}

Analyses on the consumption practices of the community studied point to the market reasoning mechanism. Consumers perceive very little the environmental impact resulting from their consumption habits, and when they do, even being aware of the environmental damage brought about by their practices, they would rather not be concerned about them. In the reality studied, the consumption acts tend to lack reflection, as well as meet the needs for practicality and symbolic consumption, which refers to the historic-cultural values of the contemporary society. Regarding the post-consumption or disposal phase, some ecologic practices were observed, such as using specific places for composts and sorting waste previously for individual collectors or for the public sorted waste collection, according to some interviewees.

According to this, Touraine (1992) considers acknowledging the formation of culture and social relationships that establish within a specific historic-social context as being fundamental for one to understand the 
symbolic mechanisms and the reasoning that emerge and can be noticed from the citizens' choices in their daily practices. The return of the subject must be thought of based on the historic contexts and the various argumentations that are built in the programmed society, according to this author. Thus, it is understood that the German descent of most residents in Estrela should be taken into account when designing environmental awareness strategies.

The dimensions of environmental knowledge that prevail in the community's consumption actions tend to be triggered by the need of choosing among aspects related to economic, technological and social dimensions, at the expense of ethical and natural aspects, which would point to a citizen-like consumption.

There is no circulation of environmental information in the sociability spaces beyond family and educative entities, which points to another sustainability strategy that can be created. In other words, it is necessary to invest in information that highlights the ethical and natural dimensions, as previously said, as well as in the social and communicational-mediatic ones.

It is understood that the consumption practices might be useful to think about and outline the construction of environmental citizenship in case there is circulation of qualified environmental information, thus generating public discussion on environmental themes, which is already happening in an isolated way with the role that was assigned to schools as venues for 'environmental education'. However, the excessive responsibility transferred to school of a role that should be of every social group might result in the decreased power of this formal educative venue.

It is also necessary that other groups, which are venues of the organized civil society, take over the role as social-environmental education actors. If a single actor's reasoning mechanism remains, one will not move from the status of individual relating with society and nature; therefore, consumers will not take over the role of historical subjects or regional sustainable development agents.

One must still bear in mind the need for the public organs in charge of environmental education to invest in projects whose target audience is the social groups mentioned by the consumers, so as to stimulate critical reflection on each one's interaction with the environment.

Thus, there may be a relationship between consumption practices and the construction of citizenship, as far as the debate on the relationships between environmental and consumption issues, based on the role each one plays in this context, which requires the establishment of environmental communication policies addressing the private scopes of sociability.

\section{RESUMO}

$\mathrm{O}$ artigo reflete sobre as relações entre as práticas cotidianas e o consumo. Compreender como se geram os conflitos, as resistências e os consensos a partir das práticas de consumo no cotidiano abre possibilidades para refletir sobre a construção da sustentabilidade no contexto de diversidade, uma das marcas do mundo globalizado. Neste contexto sociocultural, a questão central que surge é: o consumo pode gerar práticas de cidadania? As noções de sujeito e de agente ajudam a pensar a ação coletiva e os processos de subjetivação e suas interferências no comportamento coletivo de consumir. A partir de dados empíricos da pesquisa realizada em 2007 no município de Estrela, na região do Vale do Taquari - RS (Sul do Brasil), sobre práticas de consumo de uma realidade local, foi possível concluir que diferentes lógicas e valores permeiam as práticas cotidianas de consumo. A construção da cidadania a partir das práticas de consumo depende da reflexividade do sujeito sobre suas práticas cotidianas, o que passa pela circulação de informação ambiental com base nos espaços de sociabilidade.

Palavras-chave: consumo, cotidiano, práticas ambientais, cidadania, sujeito.

\section{REFERENCES}

BARbosa L. 2004. Sociedade de consumo. Rio de Janeiro: ed., Zahar, $68 \mathrm{p}$.

BARRos LV. 2004. A nova lei do direito à informação ambiental. R Spei 5(1): 7-13.

Baudrillard J. 1995. A Sociedade de Consumo. Lisboa: Edições 70, 213 p.

DALlari DA. 1998. Direitos humanos e cidadania. São Paulo: Moderna, $80 \mathrm{p}$.

Featherstone M. 1995. Cultura de Consumo e Pós-Modernismo. São Paulo: Studio Nobel, 223 p.

GARCIA CANCLINI N. 1995. Consumidores e cidadãos: conflitos multiculturais da globalização. Rio de Janeiro: UFRJ, 266 p. 
IBGE - Instituto BRAsileiro DE GEOgRAFIA E EstaTÍSTICA. 2008. Cidades. Available online at:

$<$ http://www.ibge.gov.br/cidadesat/topwindow.htm?1> Accessed July 2008.

KOTLER P. 1994. Administração de marketing: análise, planejamento, implementação e controle. São Paulo: Atlas, $848 \mathrm{p}$.

LIPOVETSKY G. 1989. O império do efêmero: a moda e seu destino nas sociedades modernas. São Paulo: Companhia das Letras, $294 \mathrm{p}$.

LOUREIRO CFB. 2002. Educação ambiental e movimentos sociais na construção da cidadania ecológica e planetária. In: Loureiro CFB, LAYRARGUES PP AND CASTRO RS (Orgs), Educação ambiental: repensando o espaço da cidadania. São Paulo: Cortez, 255 p.

Marshall TH. 1967. Cidadania e Classe Social. Brasília: Fundação Projeto Rondon, 220 p.

MeluCCi A. 2004. O jogo do eu: a mudança de si em uma sociedade global. São Leopoldo: Unisinos, 184 p.

PAES MHS. 1997. A década de 60: rebeldia, contestação e repressão política. São Paulo: Ática, 95 p.
PAOLI MC. 1992. Memória, História e cidadania: o direito ao passado. In: Secretaria Municipal da Cultura. $\mathrm{O}$ direito à memória: patrimônio e cidadania. São Paulo: DPH, p. 25-29.

Portilho F. 2005. Sustentabilidade ambiental, consumo e cidadania. São Paulo: Cortez, 255 p.

RochA E. 2005. Culpa e prazer: imagens do consumo na cultura de massa. In: COMUNICAÇÃO, MídIA E CONSuMO. Available at:

$<$ http://revcom.portcom.intercom.org.br/index.php/ comunicacaomidiaeconsumo/article/view/5088/4701>. Accessed 31 August 2008.

Touraine A. 1992. Crítica da modernidade. Lisboa: Piaget, $431 \mathrm{p}$.

Touraine A. 2006. Um novo Paradigma: para compreender o mundo de hoje. Petrópolis RJ: Vozes, 261 p.

Vergara SC. 2004. Projetos e relatórios de pesquisa em administração. São Paulo: Atlas, 92 p.

VIEIRA L. 2001. Os argonautas da cidadania: a sociedade civil e a globalização Rio de Janeiro: Record, 403 p. 